\title{
HUBUNGAN FAKTOR SOCIODEMOGRAFI DAN SANITASI LINGKUNGAN DENGAN KEJADIAN DIARE DI WILAYAH PUSKESMAS BARA BARAYA KOTA MAKASSAR
}

\author{
Sociodemography and Environmental Health Factors Associated with \\ Diarrheal Desease in Health Care Center of Bara Baraya Makassar
}

\author{
Baharuddin Sunu', Hanafi A Kadir ${ }^{2}$, Ardi $^{2}$ \\ ${ }^{1}$ Politeknik Kesehatan Muhammadiyah Makassar \\ ${ }^{2}$ Universitas Indonesia Timur \\ baharuddinsunu@gmail.com
}

\begin{abstract}
ABSTRAK
Penyakit diare merupakan salah satu masalah kesehatan masyarakat di negara-negara berkembang dan sampai saat ini masih merupakan salah satu penyakit endemis dan masih sering menimbulkan kejadian luar biasa (KLB) di masyarakat. Jenis penelitian yang dilakukan ini adalah merupakan penelitian observasional dengan menggunakan rancangan potong lintang (cross sectional study), yang bertujuan untuk mengetahui apakah ada hubungan antara factor sociodemografi (pendidikan, pekerjaan) dan sanitasi lingkungan (pembuangan air limbah, pembuangan sampah dan penyediaan air bersih) dengan kejadian diare di puskesmas bara baraya Makassar. Populasi penelitian adalah penduduk yang bertempat tinggal di wilayah kerja puskesmas Bara-baraya kota Makassar dengan jumlah penduduk sebesar 2.310 jiwa dan jumlah sampel yang didapatkan sebanyak 209 kk dengan cara systematic random sampling. Pengumpulan data dilakukan dengan cara wawancara menggunakan kuesioner. Analisis statistik yang digunakan adalah uji Chi-Square. Hasil analisis menunjukkan adanya hubungan yang signifikan antara faktor pendidikan, pekerjaan, pembuangan air limbah, pembuangan sampah dan penyediaan air bersih terhadap kejadian diare pada masyarakat. Disarankan agar adanya upaya promotif seperti penyuluhan secara berkelanjutan dan usaha peningkatan sanitasi lingkungan di daerah tersebut.
\end{abstract}

\section{Kata kunci : diare, pendidikan,pekerjaan,sanitasi lingkungan.}

\section{ABSTRACT}

Diarrhea is one of the public health problems in developing countries and until now it is still one of the endemic diseases and still often causes outbreaks in the community. This research is an observational study using a cross-sectional study, which aims to determine whether there is a relationship between sociodemographic factors (education and employment) and environmental sanitation (waste water disposal, garbage disposal and clean water supply) with the incidence of diarrhea at the bara baraya health care center in Makassar. The population was residents residing in the working area of the Bara-baraya health care center in Makassar city with a population of 2,310 people and the number of samples obtained 209 people by systematic random sampling. Data collection using a questionnaire. The statistical analysis used is the Chi-Square test. The results of the analysis indicate a significant relationship between factors of education, employment, waste water disposal, garbage disposal and the provision of clean water to the incidence of diarrhea in the community. It is recommended that there be promotive efforts such as ongoing counseling and efforts to improve environmental sanitation in the area.

\section{Key Word : diarrhea, education, employment, environmental sanitation}

\section{PENDAHULUAN}

Penyakit diare merupakan salah satu masalah kesehatan masyarakat di negara-negara berkembang. Diperkirakan lebih dari 1,3 milyar serangan dan 3,2 juta kematian per tahun pada balita disebabkan oleh diare. Setiap anak mengalami episode serangan diare ratarata 3,3 kali setiap tahun. Lebih kurang $80 \%$ kematian terjadi pada anak yang berusia kurang dari dua tahun (Widoyono, 2008). Penyakit diare merupakan suatu masalah yang mendunia. Seperti sebagian besar penyakit anak-anak lainnya, penyakit diare tersebut 
jauh lebih banyak terdapat di Negara berkembang daripada Negara maju, yaitu 12,5 kali lebih banyak di dalam kasus mortalitas (WHO, 2008).

Penyakit diare di Indonesia sampai saat ini masih merupakan salah satu penyakit endemis dan masih sering menimbulkan kejadian luar biasa (KLB) di masyarakat oleh karena seringnya terjadi peningkatan kasus-kasus pada saat atau musim-musim tertentu yaitu pada musim kemarau dan pada puncak musim hujan .Penyakit diare masih termasuk dalam 10 penyakit tersebar di Indonesia tahun 2014 dan menduduki urutan kelima dari 10 penyakit terbesar (Profil Kesehatan Indonesia, 2015).

Pada tahun 2008 dilaporkan terjadinya kejadian luar biasa (KLB) Diare di !5 provinsi dengan jumlah penderita sebanyak 8.443 orang, jumlah kematian 209 orang atau Case Fatality Rate $2,48 \%$. Hal tersebut utamanya disebabkan oleh rendahnya ketersediaan air bersih, sanitasi yang buruk dan perilaku hidup tidak sehat (profil kesehatan Indonesia.2008).

Penyakit diare sampai kini masih menjadi masalah kesehatan masyarakat, walaupun secara umum angka kesakitan masih berfluktuasi, dan pada tahun 2013 tidak terjadi lagi kematian akibat diare, namun penyakit diare ini masih menjadi skala prioritas dalam kegiatan penanggulangannya. Kasus diare yang dilaporkan oleh 39 Puskesmas se Kota Makassar sampai dengan Desember 2013 sebanyak 28.908 kasus. Angka kesakitan (Incidence Rate/IR) penyakit diare pada tahun 2013 sebesar 21,3 per 1.000 penduduk, angka ini menurun dari tahun 2012 sebesar $21,6 \%$ per 1.000 penduduk dengan kasus 29.265.(Profil Kesehatan Kota Makassar 2013). Penyakit Diare menduduki peringkat pertama untuk jenis penyakit menular yang mewabah di kota Makassar pada tahun 2009 dengan jumlah kasus sebesar 45.014 dengan angka kematian sebesar 8 orang. Angka ini menurun pada tahun 2010 menjadi 39.740 kasus tanpa kasus kematian yang terpusat pada usia 12 bulan sampai 4 tahun( Amin.2012)

Penyakit diare di puskesmas Bara-baraya masih merupakan masalah kesehatan masyarakat setiap tahunnya. Pada tahun 2016 tercatat penyakit diare menempati urutan ke dua berdasarkan pola kesakitan 10 besar penyakit rawat jalan di Puskesmas, setelah penyakit infeksi akut lain pada saluran pernapasan bagian atas, dengan angka kesakitan 22,53 per 1000 penduduk.

Berdasarkan latar belakang di atas, maka rumusan masalah pada penelitian ini adalah apakah tingkat pendidikan, pekerjaan dan sanitasi lingkungan (penyediaan air bersih, pengolahan air limbah dan pengolahan sampah rumah tangga) merupakan faktor yang berhubungan dengan kejadian diare di wilayah puskesmas Bara-baraya kota Makassar ?

Penelitian ini bertujuan untuk mengetahui faktor faktor yang berhubungan dengan kejadian diare di wilayah Puskesmas Bara-baraya kota Makassar.

\section{BAHAN DAN METODE}

Jenis penelitian adalah penelitian observasional dengan menggunakan rancangan potong lintang (cross sectional study), dengan maksud bahwa semua pengukuran variabel penelitian dilakukan pada periode waktu yang sama.

Populasi penelitian adalah penduduk yang bertempat tinggal di wilayah kerja puskesmas Bara-baraya kota Makassar dengan jumlah penduduk sebesar 2.310 jiwa dengan jumlah kepala keluarga (KK) sebesar $461 \mathrm{KK}$.

Sampel dalam penelitian ini adalah kepala keluarga (KK) yang bertempat tinggal di wilayah kerja puskesmas Bara-barayakotaMakassar yang terpilih sebagai sampel. Teknik pengambilan sampel dilakukan dengan cara Sistematic Random Sampling (Lemeshow.1997), dan dari hasil perhitungan diperoleh jumlah sampel 
sebanyak 209 kk.. Data primer dikumpulkan dengan teknik wawancara menggunakan acuan kuesioner, sedangkan data sekunder dilakukan dengan cara observasi pencatatan dan pelaporan di wilayah kerja puskesmas Bara baraya kota Makassar, kemudian dilakukan analisis univariat untuk mengetahui karakteristik responden. Dan analisis bivariat untuk melihat pengaruh antara variabel independen terhadap variabel dependen dengan menggunakan Uji Chi Square.

\section{HASIL PENELITIAN}

\section{Analisis Univariat}

Tabel 1. Distribusi Karakteristik Responden di Puskesmas Bara Baraya Tahun 2017

\begin{tabular}{llll}
\hline Karakteristik & $\mathrm{n}$ & $\%$ \\
\hline
\end{tabular}

Kejadian diare

Ya

Tidak

Tingkat pendidikan

$$
\text { Kurang }
$$

Cukup

Pekerjaan

Bekerja

Tidak Bekerja

Penyediaan Air Bersih

Tidak memenuhi syarat

Memenuhi syarat

85

Pengolahan Sampah

Tidak memenuhi syarat

Memenuhi syarat

Sarana Pembuangan Air Limbah

Tidak memenuhi syarat

Memenuhi syarat

Sumber: Data primer 2016

Tabel 1 menunjukkan bahwa sebagian besar masyarakat yang tinggal di wilayah Puskesmas Bara-baraya yang terpilih sebagai sampel menderita diare yaitu sebesar $61,7 \%$, sedangkan yang tidak diare hanya $38,3 \%$, dan tingkat pendidikann maksimal hanya tamat SLTP (kurang) yaitu sebesar $61,7 \%$, sedangkan yang tingkat pendidikannya minimal tamat SLTA (cukup) hanya 38,3\%. Untuk responden yang memiliki pekerjaan yaitu sebesar $63,6 \%$, sedangkan yang tidak bekerja hanya $36,4 \%$. 
Untuk variable sanitasi lingkungan, sampel yang memiliki sarana air bersih yang tidak memenuhi syarat kesehatan yaitu sebesar 59,3\%, sedangkan yang memenuhi syarat kesehatan hanya $40,7 \%$, dan untuk sampel yang pengolahan sampahnya tidak memenuhi syarat kesehatan yaitu sebesar $63,6 \%$, sedangkan yang memenuhi syarat kesehatan hanya $36,4 \%$. Untuk sarana pembuangan air limbah, yang tidak memenuhi syarat kesehatan sebesar $64,6 \%$, sedangkan yang memenuhi syarat kesehatan hanya $35,4 \%$.

\section{Analisis bivariat}

Tabel 2. Hubungan faktor Sociodemografi dan Sanitasi lingkungan dengan kejadian diare.

\begin{tabular}{|c|c|c|c|}
\hline \multirow{3}{*}{ Variabel } & \multicolumn{2}{|c|}{ Kejadian Diare } & \multirow[b]{2}{*}{ Total } \\
\hline & $\mathrm{Ya}$ & Tidak & \\
\hline & $\mathrm{n}$ & $\%$ & $\%$ \\
\hline
\end{tabular}

Tingkat pendidikan

$\begin{array}{lcccccc}\text { Kurang } & 117 & 90,7 & 12 & 9,3 & 129 & 100 \\ \text { Cukup } & 12 & 15,0 & 68 & 85,0 & 80 & 100\end{array}$

Pekerjaan

$\begin{array}{lcccccc}\text { Bekerja } & 116 & 87,2 & 17 & 12,8 & 133 & 100 \\ \text { Tidak Bekerja } & 13 & 17,1 & 63 & 82,9 & 76 & 100\end{array}$

Penyediaan Air Bersih

$\begin{array}{lcccccc}\text { Tidak memenuhi syarat } & 114 & 91,9 & 10 & 8,1 & 124 & 100 \\ \text { Memenuhi syarat } & 15 & 17,6 & 70 & 82,4 & 85 & 100\end{array}$

Pengolahan sampah

$\begin{array}{lllllll}\text { Tidak memenuhi syarat } & 117 & 88,6 & 16 & 12,0 & 133 & 100 \\ \text { Memenuhi syarat } & 12 & 15,8 & 64 & 84,2 & 76 & 100\end{array}$

Sarana pembuangan air limbah

\begin{tabular}{lllllll} 
Tidak memenuhi syarat & 119 & 88,1 & 16 & 11,9 & 135 & 100 \\
Memenuhi syarat & 10 & 13,5 & 64 & 86,5 & 74 & 100 \\
\hline
\end{tabular}

Sumber: Data Primer 2016

\section{PEMBAHASAN}

\section{Hubungan tingkat pendidikan dengan kejadian diare.}

Hasil penelitian diperoleh sebagian besar sampel yang terpilih memiliki tingkat pendidikan maksimal hanya tamat SLTP atau termasuk kategori kurang yaitu sebesar $61,7 \%$, bila dikaitkan dengan kejadian diare diperoleh sebagian besar masyarakat yang menderita diare memiliki tingkat pendidikan yang kurang yaitu sebesar 90,7\%. 
Hasil analisis statistik diperoleh nilai $p(0.000)<0.05$, ini berarti secara statistik ada hubungan antara tingkat pendidikan dengan penurunan kejadian diare, artinya bahwa semakin tinggi tingkat pendidikan masyarakat akan memberikan kontribusi terhadap penurunan kejadian diare.

Hasil penelitian ini didukung oleh penelitian yang dilakukan di Jebres kota Surakarta oleh Jonatan Eko (2014) bahwa tingkat pendidikan dari lamanya mengikuti pendidikan ditemukan bahwa risiko anak balita pada kelompok ibu yang mengikuti pendidikan dibawah 9 tahun (maksimal tamat SLTP) 2,5 kali lebih besar untuk menderita diare dibandingkan kelompok yang masa pendidikannya lebih dari 9 tahun ( minimal tamat SMA). Hasil penelitian ini membuktikan bahwa pengaruh risiko tingkat pendidikan terhadap diare bersifat proxy yaitu mempengaruhi kebiasaannya dalam higiene perorangan dan praktek pemanfaatan sarana sanitasi lingkungan

\section{Hubungan pekerjaan dengan kejadian diare}

Hasil penelitian diperoleh sebagian besar masyarakat yang terpilih sebagai sampel memiliki pekerjaan yaitu sebesar 63,6\%. Bila dikaitkan dengan kejadian diare, diperoleh sebagian besar masyarakat yang menderita diare mempunyai status bekerja yaitu sebesar $87,2 \%$.

Hasil analisis statistik diperoleh ada hubungan antara pekerjaan dengan penurunan kejadian diare, dengan nilai $\mathrm{p}(0.000)<0.05$. Iniberarti bahwa seseorang yang memiliki pekerjaan secara tidak lansung akan berpengaruh terhadap tingkat pendapatan dan tingkat pendapatan sangat berkaitan dengan pemenuhan kebutuhan hidup termasuk pemenuhan kebutuhan akan kesehatan.

Hasil penelitian ini didukung oleh penelitian yang dilakukan di Klaten oleh Krisnawan dan Suharyanto (1996), ditemukan bahwa kelompok ibu yang bekerja diluar rumah mendapatkan risiko anaknya menderita diare sebesar 1,83 kali lebih besar dibandingkan kelompok ibu yang bekerja di dalam rumah.Berbeda dengan hasil penelitian di Tondano (Marlina,dkk. 2015) yang menunjukkan bahwa tidak ada perbedaan yang bermakna antara kejadian diare pada orang yang bekerja dan yang tidak bekerja.

\section{Hubungan penyediaan air bersih dengan kejadian diare}

Hasil analisis statistik diperoleh ada hubungan antara sarana air bersih yang tidak memenuhi syarat kesehatan dengan kejadian diare, ini berarti sarana air bersih memberikan kontribusi terhadap kejadian diare. Diare sering menyebabkan wabah yang dapat membahayakan bagi penderita maupun orang di sekitarnya yang bertempat tinggal di daerah dengan sarana air bersih kurang memenuhi syarat kesehatan. Sebagai penyakit menular, penyakit diare ini penularannya dapat berupa infeksi seperti virus, bakteri dan lain sebagainya. Penyakit ini biasanya juga termasuk dalam penyakit yang sumber penularannya melalui perantaraan air atau sering disebut sebagai water borne diseases. Agen penyebab penyakit diare sering dijumpai pada sumber air yang sudah terkontaminasi dengan agen penyebab penyakit, air yang sudah tercemar apabila digunakan oleh orang sehat bisa membuat orang tersebut terpapar dengan agen penyebab penyakit diare.

Snow pada tahun 1855, sebagai orang pertama yang membuktikan hubungan antara penyakit kolera dengan air, ini membuktikan bahwa air sangat berperan dalam terjadinya suatu penyakit(Muhajirin.2014). Penelitian yang dilakukan oleh J. Baltazar dkk di Filipina tahun 1984 mengemukakan bahwa dengan penyediaan air bersih dan sanitasi akan mengurangi diare $20 \%$, sedangkan diare yang disebabkan oleh bakteri patogen berkurang $40 \%$ 
dibandingkan daerah tanpa air bersih dan sanitasi yang tidak baik (Nuraeni.2014).

\section{Hubungan pengolahan sampah dengan kejadian diare}

Hasil penelitian diperoleh bahwa sebagian besar sampel yang terpilih memiliki sarana pembuangan sampah yang tidak memenuhi syarat kesehatan yaitu sebesar $63,6 \%$. Bila dikaitkan dengan kejadian diare diperoleh sebagian besar masyarakat yang menderita diare memiliki pengolahan sampah yang tidak memenuhi syarat kesehatan yaitu sebesar $88.0 \%$.

Hasil analisis statistik diperoleh bahwa ada hubungan antara pengolahan sampah dengan kejadian diare, ini berarti masyarakat yang pengolahan sampahnya tidak memenuhi syarat kesehatan dapat menjadi penmicu terjadinya diare. Sampah yang tidak dikelola dengan baik akan menjadi tempat berkembang biaknya serangga pembawa penyakit, menimbulkan bau tidak sedap dan mempengaruhi estetika.

\section{Hubungan Antara Sarana Pembuangan Air Limbah dengan Kejadian Diare}

Hasil penelitian diperoleh bahwa sebagian besar masyarakat memiliki sarana pembuangan air limbah yang tidak memenuhi syarat kesehatan yaitu sebesar $64.6 \%$. Bila dikaitkan dengan kejadian diare diperoleh bahwa sebagian besar masyarakat yang menderita diare memiliki sarana pembuangan air limbah yang tidak memenuhi syarat kesehatan yaitu sebesar $88.1 \%$.

Hasil analisis statistik diperoleh adanya hubungan antara sarana pembuangan air limbah yang tidak memenuhi syarat kesehatan dengan kejadian diare, artinya bahwa sarana pembuangan air limbah yang tidak memenuhi syarat kesehatan memberikan kontribusi terhadap kejadian diare.

Pembuangan air limbah yang dilakukan secara tidak sehat atau tidak memenuhi syarat kesehatan dapat menyebabkan terjadinya pencemaran pada permukaan tanah dan sumber air. Dengan demikian untuk mencegah atau mengurangi kontaminasi air limbah terhadap lingkungan, maka limbah harus dikelola dengan baik, sehingga air limbah tidak menjadi tempat berbiaknya bibit penyakit seperti lalat, tidak mengotori sumber air, tanah dan tidak menimbulkan bau.

\section{KESIMPULAN DAN SARAN}

Dari hasil penelitian diatas dapat disimpulkan bahwa ada hubungan antara tingkat pendidikan, pekerjaan dan sanitasi lingkungan (penyediaan air bersih, pengolahan air limbah dan pengolahan sampah rumah tangga) dengan kejadian diare dan perlunya upaya - upaya promotif seperti penyuluhan mengenai sarana pembuangan sampah, sarana air bersih dan sarana pembuangan air limbah agar masyarakat dapat mempertahankan kebiasaan hidup sehat yang telah mereka miliki serta perlunya penelitian lanjutan untuk mengetahui faktor lain yang berhubungan dengan kejadian diare.

\section{DAFTAR PUSTAKA}

Amin Rahman,dkk.2012. Faktor-faktor yang mempengaruhi kejadian diare pada balita di wilayah kerja puskesmas Barang Lompo kecamatan Ujung Tanah.http://repositoryunhas.ac.id..

Jonathan Eko.2014. Hubungan antara Tingkat Pendidikan Formal Ibu terhadap Kejadian Diare pada Balita di Wilayah Keraja Puskesmas Pucangsawit Kecamatan Jebres kota Surakarta.Skripsi Universitas Muhammadiyah Surakarta.

http://ums.ac.id. 
Krisnawan, IK,B., Supardi,S., 1996, Faktor-faktor Risiko yang Mempengaruhi Kejadian Diare Berdarah pada Usia Balita di Kabulaten Klaten, Berita Kedokteran Masyarakat, XII (2). 30 - 40.

Lemeshow. 1997. Besar Sampel Dalam Penelitian Kesehatan. Gadjah Mada University Press.Yogyakarta.

Marlina,dkk.2015. Hubungan faktor sosiodemografi dan lingkungan dengan diare pada anak balita di daerah aliran sungai Tondano. Jurnal e-Clinic (eCl), Volume 3, Nomor 3, September-Desember 2015

Muhajirin. 2014. Hubungan antara praktek personal Higiene ibu balita dan sarana sanitasi lingkungan kejadian diare di Kabupaten Cilacap. Tesis Universitas Diponegoro semarang.http://undip.ac.id.

Nuraeni,asti.2012. Hubungan Penerapan PHBS keluarga dengan Kejadian Diare pada balita Di Kelurahan Tamangmas di kota Semarang.Tesis Universitas Indonesia.http://Ul.ac.id.

Profil Kesehatan Indonesia.2015

Profil Kesehatan Indonesia.2008

Profil Kesehatan Kota Makassar.2013.

WHO. 2008. Indikator Perbaikan Kesehatan Lingkungan Anak. Jakarta.EGC

Widiyono.2008. Penyakit Tropis : Epidemiologi, Penularan, Pencegahan, dan Pemberantasannya. Jakarta; Erlangga. 